\title{
Economics of Different Grafting Methods on Pecan Nut (Carya illinoensis Wangenh) under Intermediate Agro-Climatic Conditions of Jammu and Kashmir
}

\author{
Gagan Mehta*, Rajesh Kumar, V.K. Wali, Akash Sharma, S.K. Mehta, \\ Anil Bhat and Manmohan Lal
}

Division of Fruit Science, SKUAST-Jammu, India

*Corresponding author

A B S T R A C T

\begin{tabular}{|l|}
\hline K e y w o r d s \\
Pecan, Economics, \\
Grafting, B: C ratio, Net \\
returns
\end{tabular}

\section{Introduction}

The Pecan (Carya illenoinensis Wang.) belonging to family Jug land aceae was originated from the south east of U.S.A. It is considered as the "queen of nuts" in U.S.A. because of its value both as wild and cultivated nut (Woodroof, 1979). Their nuts have high nutritional and calorific value. So, pecan is more acceptable in comparison to other nuts. Pecan nut contains high content of proteins $(12.5 \%)$, fats $(71.42 \%), \mathrm{P}_{2} \mathrm{O}_{5}(0.46 \%)$, $\mathrm{K}_{2} \mathrm{O}(0.23 \%)$ and is rich in oil content and some varieties have shown as high as $76 \%$ oil. Pecans are good source of protein and unsaturated fats like walnuts, pecans are rich in omega-6 fatty acids, although pecans contain about half as much omega-6 as walnuts. Besides having large potential as nut its timber is also very expensive and used in gun-stock, carving, cabinet manufactures of high class and many other use. It requires warm temperate climate. It requires 240 to 280 days growing under warm climate with a mean temperature of above $26.7^{\circ} \mathrm{C}$ (Naira et $a l ., 2013)$. It is one of the most important nut fruits of the world ranking fifth in production. Pecan nut is the one of the most important temperate nuts grown in India. In India, it is mainly grown in Jammu and Kashmir, and Himachal Pradesh. In Jammu and Kashmir state, pecan nut is being successfully grown in 
Rajouri, Poonch, Udhampur, Kathua, Reasi, Doda, Kishtwar and Ramban districts of Jammu division and Baramula and Kupwara districts of Kashmir division. The total area under pecan nut production is increasing due its high economic returns and adaptation to intermediate zone of $\mathrm{J} \& \mathrm{~K}$ state of India. The available data revealed that the area under pecan nut in Jammu and Kashmir is about 656.00 hectares, whereas, the production perannum was to the tune of $13.00 \mathrm{MT}$ (Anonymous, 2015).

The economics of best grafting method is to be worked out to get maximum benefit with minimum cost as it helps to raise the socioeconomic conditions of the orchardists by giving more income per unit area. Thus, by keeping the beneficial aspects of grafting into consideration, the present investigation was undertaken to assess the economic feasibility of different grafting methods.

\section{Materials and Methods}

The present investigation entitled "Standardization of method and time of grafting in pecan (Carya illinoensis Wangenh) under intermediate agro-climatic zones of Jammu and Kashmir" was carried out in the experimental farm of Regional Agriculture Research Station (RARS), Rajouri, Tandwal, SKUAST-Jammu during 2016. The mean annual rainfall is about $769 \mathrm{~mm}$ (26.3 inch). The altitude of the place is $915 \mathrm{~m}$ from mean sea level. The experiment was carried out by grafting 1800 plants with three different grafting methods viz., Tongue grafting, Cleft grafting, Side grafting on four different dates viz., 4th week of February, 1st Week of March, 2nd week of March and 3rd week of March. Total number of treatments were 12 with 50 plants per treatment so that the total plants grafted per treatment were 600. The experiment were laid in a Factorial Randomized Block Design with three replications. The economics of using different grafting methods of Pecan nut have been worked out by calculating net returns from each of the three methods. In this analysis, only the cost of the treatments for different grafting methods and cultural management practices has been considered for estimating the cost. This cost includes material as well as labour cost of the treatment. Thus the net returns are bas $\mathrm{d}$ on the following components.

\section{Cost of treatment}

The cost incurred on each treatment for 1800 pecan nut plants was worked out by taking into consideration the cost of variable inputs only viz., rootstock, scion, grafting cost, land preparation, laboure charge and FYM etc.

Variable cost $(\mathrm{Vc})=\mathrm{C}_{1}+\mathrm{C}_{2}+\mathrm{C}_{3}+\ldots \ldots \ldots \mathrm{C}_{\mathrm{n}}$

\section{Gross income}

Grosss income was calculated by multiplying the grafted plant of a given treatment by the sale price of the plant.

Gross income $(\mathrm{GI})=$ Grafted plant $\times$ sale price

In order to evaluate most profitable treatment, economic analysis of treatment was worked out in terms of net returns and benefit: cost (B: $C)$ ratio. The net returns and $B$ : $C$ ratio was calculated as follows.

Net returns were calculated by deducting the cost of grafting from the gross income.

Net income $=$ Gross income - Cost of treatment

\section{Benefit Cost Ratio (BCR)}

The benefit cost ratio (BCR) of an investment is the ratio of the discounted value of all cash inflows to the discounted value of all cash 
outflows during the life of the project. It can be estimated as follows

$$
\mathrm{BCR}=\quad \sum_{\mathrm{t}=0}^{\mathrm{n}}\left\{\left(\mathrm{B}_{\mathrm{t}}\right) /(1+\mathrm{r})^{\mathrm{t}} / \sum_{\mathrm{t}=0}^{\mathrm{n}}\left[\left(\mathrm{C}_{\mathrm{t}}\right) /(1+\mathrm{r})^{\mathrm{t}}\right\}\right.
$$

Where,

$\mathrm{B}_{\mathrm{t}}=$ gross returns in time $\mathrm{t}$

$\mathrm{C}_{\mathrm{t}}=$ variable cost in time $\mathrm{t}$

$r=$ rate of interest

$\mathrm{t}=$ time period $(\mathrm{t}=0,1,2$, $\mathrm{i}, \ldots \ldots, 30)$

\section{Results and Discussion}

The data pertaining to the effect of time and method of propagation on cost and return analysis of grafting methods of pecan nut plants is presented in Table1. It revealed that the total cost for grafting of pecan nut plants upto their survival was found to be (₹ 32.02) per plant, ( $₹$ 1701.00) per plot, ( $₹$ 20415.60) for 12 plots and (₹ 61246.80) for 36 plots. Each method of grafting (tongue, cleftandside) contains 12 plots i.e. 600 plants.

It was observed from the table that cost incurred on root stock for 12 plots of each method was found to be highest (₹ 9000.00) followed by grafting ( $₹$ 3300.00), scion ( $₹$ 3000.00), labour charges (₹ 2400.00), land preparation (₹ 600.00) and FYM (₹ 600.00).

The data pertaining to the net returns is presented in Table2. It is evident from the table that after different survival rate of each of the three methods, tongue grafting gave maximum net returns (₹ 5384.20) which was followed by cleft grafting ( $₹$ 2984.20). The lowest net returns (₹ 484.20) were found inside grafting.

Table.1 Cost and return analysis of grafting methods of pecan nut plants

\begin{tabular}{|c|c|c|c|c|}
\hline \multirow[t]{2}{*}{ Items } & $\begin{array}{l}\text { Cost per } \\
\text { plant (₹) }\end{array}$ & $\begin{array}{c}\text { Cost per plot } \\
(₹)\end{array}$ & $\begin{array}{l}\text { Cost for } 12 \text { plots } \\
\text { (₹ ) }\end{array}$ & $\begin{array}{c}\text { Cost for } 36 \\
\text { plots (₹) }\end{array}$ \\
\hline & $\begin{array}{c}\text { Tongue/Cle } \\
\text { ft/Side }\end{array}$ & $\begin{array}{c}\text { Tongue/Clef } \\
\text { t/Side }\end{array}$ & $\begin{array}{c}\text { Tongue/Cleft/Si } \\
\text { de }\end{array}$ & $\begin{array}{l}\text { Tongue/Cleft } \\
\text { /Side }\end{array}$ \\
\hline \multicolumn{5}{|l|}{ Cost Analysis } \\
\hline Rootstock & 15 & 750 & 9000 & 27000 \\
\hline Scion & 5 & 250 & 3000 & 9000 \\
\hline Land preparation & 1 & 50 & 600 & 1800 \\
\hline Grafting & 5.5 & 275 & 3300 & 9900 \\
\hline Irrigation (electricity used) & 0.10 & 5 & 60 & 180 \\
\hline $\begin{array}{l}\text { Insecticide (chlorpyrifos + } \\
\text { carbofuran) }\end{array}$ & 0.50 & 25 & 300 & 900 \\
\hline Farmyard manure & 1.0 & 50 & 600 & 1800 \\
\hline $\begin{array}{l}\text { Total labour (weeding }+ \\
\text { irrigation }+ \text { insecticide }+ \\
\text { rootstock planting }+ \text { uprooting } \\
\text { of plants) }\end{array}$ & 4.00 & 200 & 2400 & 7200 \\
\hline Totalvariablecost $(₹)$ & 32.10 & 1605 & 19260 & 57780 \\
\hline $\begin{array}{l}\text { Interestonworkingcapital@6 } \\
\% \text { perannum }\end{array}$ & 1.92 & 96 & 1155.6 & 3466.8 \\
\hline Totalcost(₹) & 34.02 & 1701.00 & 20415.60 & 61246.80 \\
\hline
\end{tabular}


Table.2 Benefit: cost ratio analysis of different grafting methods of pecan nut

\begin{tabular}{|c|c|c|c|c|c|c|c|c|c|c|c|c|c|c|c|}
\hline \multirow[t]{2}{*}{$\begin{array}{l}\text { Date of } \\
\text { Grafting }\end{array}$} & \multicolumn{3}{|c|}{$\begin{array}{l}\text { Total Number of } \\
\text { Plants (No.) }\end{array}$} & \multicolumn{3}{|c|}{$\begin{array}{c}\text { Number of plants } \\
\text { Survived }\end{array}$} & \multicolumn{3}{|c|}{$\begin{array}{c}\text { Survival percentage } \\
(\%)\end{array}$} & \multicolumn{3}{|c|}{ Price per plant (₹ ) } & \multicolumn{3}{|c|}{ Returns (₹ ) } \\
\hline & Tongue & Cleft & Side & Tongue & Cleft & Side & Tongue & Cleft & Side & Tongue & Cleft & Side & e Tongue & Cleft & Side \\
\hline $\mathbf{D}_{1}$ & 150 & 150 & 150 & 62 & 56 & 51 & 41 & 37.33 & 33.66 & 100 & 100 & 100 & 6200 & 5600 & 5100 \\
\hline $\mathbf{D}_{2}$ & 150 & 150 & 150 & 71 & 65 & 59 & 47.33 & 43.66 & 39.33 & 100 & 100 & 100 & 7100 & 6500 & 5900 \\
\hline$D_{3}$ & 150 & 150 & 150 & 67 & 61 & 55 & 44.33 & 40.33 & 36.33 & 100 & 100 & 100 & 6700 & 6100 & 5500 \\
\hline $\mathbf{D}_{4}$ & 150 & 150 & 150 & 58 & 52 & 44 & 38.66 & 34.33 & 29.33 & 100 & 100 & 100 & 5800 & 5200 & 4400 \\
\hline Total & 600 & 600 & 600 & 258 & 234 & 209 & 42.83 & 38.91 & 34.66 & & & & 25800 & 23400 & 20900 \\
\hline $\begin{array}{c}\text { Total } \\
\text { Returns (₹ ) }\end{array}$ & & & & & & & & & & & & & 25800 & 23400 & 20900 \\
\hline Cost (₹ ) & & & & & & & & & & & & & 20415.8 & 20415.8 & 20415.8 \\
\hline $\begin{array}{l}\text { Net Returns } \\
\text { (₹) }\end{array}$ & & & & & & & & & & & & & 5384.2 & 2984.2 & 484.2 \\
\hline B: C Ratio & & & & & & & & & & & & & $1: 1.26$ & 1:1.14 & 1:1.02 \\
\hline
\end{tabular}


The table further revealed that benefit: cost ratio (B: $\mathrm{C}$ ratio) was found maximum in tongue grafting $(1: 1.26)$ which was followed by cleft grafting (1: 1.14) and side grafting (1: 1.02). This might be due to high return and maximum survival percentage in tongue grafting as compared to other methods.

Similar estimates for gross income were reported by Joubert et al., (1991) in which chestnut plants were grafted with tongue grafting gave maximum returns as compared to others. These findings are in agreement with the work of Khopade (2011) in custard apple. The results were also in accordance with Germain (1983) in walnut.

Net returns were recorded highest (₹ 5384.20) in tongue grafting and lowest of (₹ 484.20) in side grafting. Benefit: Cost ratio (B: $\mathrm{C}$ ratio) was found maximum $(1: 1.26)$ in tongue grafting and minimum in side grafting (1: 1.02). From the present study it can be concluded that among the different grafting methods, tongue grafting is most suitable and economically feasible as it resulted in highest net returns under intermediate agro-climatic conditions of Jammu and Kashmir.

\section{References}

Anonymous, 2015. Directorate of Horticulture, Government of J\&K, 2015 Germain, E. 1983. The Persial walnut in Iran. Nucis Newsletter, 1: 5-6.

Joubert, B. H., Morton, J. F. and Kotze, W. 2001. Cost of chestnut plants through various vegetative propagation methods. Economics Botany, 14: 119-127.

Khopade, R. Y. 2011. Effect of dates and wrapping materials on softwood grafting of custard apple (Annona squamosa L.) Cv. Local selection under middle Gujrat conditions. MSc. Thesis Submitted To The Department of Horticulture, Stand Agriculture University, 96-98.

Naira, A., Moieza, A. and Tomar, C.S. 2013. Effect of foliar application of nutrients and bio-stimulant on growth, phenology and yield attributes of pecan nut cv. 'Western schley'. Journal of Food, Agriculture and Environment, 11(3\&4): 1222-1226.

Woodroof, J.G. 1979. Trees nuts.AVI Publishing Corporation and Incorporation Westport, Connecticut.

\section{How to cite this article:}

Gagan Mehta, Rajesh Kumar, V.K. Wali, Akash Sharma, S.K. Mehta, Anil Bhat and Manmohan Lal. 2018. Economics of Different Grafting Methods on Pecan Nut (Carya illinoensis Wangenh) under Intermediate Agro-Climatic Conditions of Jammu and Kashmir. Int.J.Curr.Microbiol.App.Sci. 7(08): 3305-3309. doi: https://doi.org/10.20546/ijcmas.2018.708.353 